\title{
P068. A suggestive case of hemiplegic migraine: a diagnostic challenge
}

\author{
Emanuela Garrone ${ }^{1}$, Corinna Garrone ${ }^{1}$, Antonella Versace ${ }^{1 *}$, Carlotta Canavese ${ }^{2}$, Margherita Conrieri ${ }^{1}$, \\ Giuseppina Migliore ${ }^{1}$, Emanuele Castagno ${ }^{1}$, Rosaura Pagliero ${ }^{1}$ \\ From Abstracts from the 1st Joint ANIRCEF-SISC Congress \\ Rome, Italy. 29-31 October 2015
}

\section{Introduction}

We describe a case of possible hemiplegic migraine (HM), whose diagnosis was challenging and required exclusion of other pathologies including ischemic and inflammatory diseases.

\section{Case report}

A 12-year-old boy was referred to our Emergency Department because of fever and temporal headache with transitory visual aura, nausea, vomiting, unilateral motor clumsiness since the day before. In his medical history, some episodes of mild headache were reported; he had family history of recurrent headache (mother and aunt). At arrival he presented a discrete general condition, paleness and fever. He was restless and confused, only partially collaborative, able to answer just simple questions and presenting left hypostenia, mild left hypoestesia and left hyporeflexia. Blood tests proved negative. Cerebral computed tomography and cerebral magnetic resonance with vascular study were all negative. The cerebrospinal fluid test showed rare leukocytes. The electroencephalographic (EEG) showed diffuse signs of suffering with prevalence at the right temporal areas, thus antiviral and cortisonic therapy were started, along with antibiotics. Further investigations included the thrombophilia panel and trans-cranial echo-color-doppler study with echocontrast, all resulted negative. During admission, the child remained afebrile with rapid resolution of headache intensity and neurological involvement; an EEG repeated two days later was normal. The clinical course and laboratory/imaging results excluded both the infectious and the ischemic hypotheses.

\footnotetext{
* Correspondence: aversace@cittadellasalute.to.it

'Centro Cefalee dell'età evolutiva, S.C. Pediatria d'Urgenza, Ospedale Infantile Regina Margherita, AOU Città della Salute e della Scienza, Turin, Italy

Full list of author information is available at the end of the article
}

The results of the genetic analysis of CACNA1A, SCN1A, ATP1A2 genes are still ongoing.

\section{Conclusions}

Our patient presented a single episode of fully reversible motor weakness with fully reversible visual and sensory symptoms, associated with headache, whose sequence of events and features is suggestive of HM, although one single episode is not sufficient for diagnosis, according to the ICHD3-beta diagnostic criteria [1,2]. In such cases, the meticulous description of aura and urgent and exhaustive investigations to search for all possible alternative causes (including stroke, tumors, infectious or inflammatory diseases, all excluded in our patient) are mandatory. Genetic tests are available to confirm the diagnosis, and in our case the result is still not available $[1,3]$.

Written informed consent to publication was obtained from the patient(s).

\section{Authors' details}

${ }^{1}$ Centro Cefalee dell'età evolutiva, S.C. Pediatria d'Urgenza, Ospedale Infantile Regina Margherita, AOU Città della Salute e della Scienza, Turin, Italy. ${ }^{2}$ S.C.D. U. Neuropsichiatria Infantile, Ospedale Infantile Regina Margherita, AOU Città della Salute e della Scienza, Turin, Italy.

\section{Published: 28 September 2015}

\section{References}

1. Headache Classification Committee of the International Headache Society (IHS): The International Classification of Headache Disorders, 3rd edition (beta version). Cephalalgia 2013, 33(9):629-808.

2. Ducros A, Denier C, Joutel A, et al: The clinical spectrum of familial hemiplegic migraine associated with mutations in a neuronalcalcium channel. N Engl J Med 2001, 345:17-24.

3. Russell MB, Ducros A: Sporadic and familial hemiplegic migraine: pathophysiological mechanisms, clinical characteristics, diagnosis, and management. Lancet Neurol 2011, 10(5):457-70, doi: 10.1016/\$1474-4422 (11)70048-5. Epub 2011 Mar 30. 
doi:10.1186/1129-2377-16-S1-A82

Cite this article as: Garrone et al:: P068. A suggestive case of hemiplegic migraine: a diagnostic challenge. The Journal of Headache and Pain 2015 16(Suppl 1):A82.
Submit your manuscript to a SpringerOpen ${ }^{\circ}$ journal and benefit from:

- Convenient online submission

- Rigorous peer review

- Immediate publication on acceptance

- Open access: articles freely available online

- High visibility within the field

- Retaining the copyright to your article

Submit your next manuscript at $>$ springeropen.com 